Biogeosciences, 10, 3605-3614, 2013

www.biogeosciences.net/10/3605/2013/

doi:10.5194/bg-10-3605-2013

(c) Author(s) 2013. CC Attribution 3.0 License.

\title{
Taking nature into lab: biomineralization by heavy metal-resistant streptomycetes in soil
}

\author{
E. Schütze ${ }^{1}$, A. Weist ${ }^{1}$, M. Klose ${ }^{1}$, T. Wach ${ }^{1,5}$, M. Schumann ${ }^{1,5}$, S. Nietzsche ${ }^{2}$, D. Merten ${ }^{3}$, J. Baumert ${ }^{4}$, J. Majzlan ${ }^{5}$, \\ and E. Kothe ${ }^{1}$ \\ ${ }^{1}$ Microbial Communication, Institute of Microbiology, Faculty of Biology and Pharmacy, Friedrich-Schiller-University Jena, \\ Neugasse 25, 07745 Jena, Germany \\ ${ }^{2}$ Centre for Electron Microscopy, Clinical Centre, Friedrich-Schiller-University Jena, Ziegelmühlenweg 1, 07743 Jena, \\ Germany \\ ${ }^{3}$ Applied Geology Institute of Geosciences, Faculty of Chemistry and Earth Sciences, Friedrich-Schiller-University Jena, \\ Burgweg 11, 07749 Jena, Germany \\ ${ }^{4}$ Max Planck Institute for Biogeochemistry Jena- Biogeochemical Processes, Hans-Knöll-Strasse 10, 07745 Jena, Germany \\ ${ }^{5}$ Mineralogy, Institute of Geosciences, Faculty of Chemistry and Earth Sciences, Friedrich-Schiller-University Jena, \\ Burgweg 11, 07749 Jena, Germany
}

Correspondence to: E. Kothe (erika.kothe@uni-jena.de)

Received: 11 December 2012 - Published in Biogeosciences Discuss.: 11 February 2013

Revised: 29 April 2013 - Accepted: 3 May 2013 - Published: 3 June 2013

\begin{abstract}
Biomineralization by heavy metal-resistant streptomycetes was tested to evaluate the potential influence on metal mobilities in soil. Thus, we designed an experiment adopting conditions from classical laboratory methods to natural conditions prevailing in metal-rich soils with media spiked with heavy metals, soil agar, and nutrientenriched or unamended soil incubated with the bacteria. As a result, all strains were able to form struvite minerals $\left(\mathrm{MgNH}_{4} \mathrm{PO}_{4} \cdot 6 \mathrm{H}_{2} \mathrm{O}\right)$ on tryptic soy broth (TSB)-media supplemented with $\mathrm{AlCl}_{3}, \mathrm{MnCl}_{2}$ and $\mathrm{CuSO}_{4}$, as well as on soil agar. Some strains additionally formed struvite on nutrient-enriched contaminated and control soil, as well as on metal contaminated soil without addition of media components. In contrast, switzerite $\left(\mathrm{Mn}_{3}\left(\mathrm{PO}_{4}\right)_{2} \cdot 7 \mathrm{H}_{2} \mathrm{O}\right)$ was exclusively formed on minimal media spiked with $\mathrm{MnCl}_{2}$ by four heavy metal-resistant strains, and on nutrient-enriched control soil by one strain. Hydrated nickel hydrogen phosphate was only crystallized on complex media supplemented with $\mathrm{NiSO}_{4}$ by most strains. Thus, mineralization is a dominant property of streptomycetes, with different processes likely to occur under laboratory conditions and sub-natural to natural conditions. This new understanding might have implications for our understanding of biological metal resistance mechanisms. We assume that biogeochemical cycles, nutri-
\end{abstract}

ent storage and metal resistance might be affected by formation and re-solubilization of minerals like struvite in soil at microscale.

\section{Introduction}

Biomineralization can be seen as the formation of crystals intracellularly or in the extracellular matrix of organisms (Lowenstam, 1981; Lowenstein and Weiner, 1989; Mann, 1983; Adele, 1998). A more detailed definition implies that biomineral deposition requires, or is associated to, a living organism (Veis, 2003). Two mechanisms are described according to the contribution of the involved organisms (Konhauser and Riding, 2012), namely biologically induced, passive and microbially controlled, and active biomineralization. The properties of the latter crystals, down to the minutiae, are meticulously controlled (Konhauser and Riding, 2012; Weiner and Dove, 2003). Consequently, interactions between living organisms and their abiotic environment need to be taken into account to understand the physico-chemical processes at or near the earth's surface, coupling biosphere and geosphere evolution (Cappellen, 2003; Schütze and Kothe, 2012). 
Almost all groups of minerals, including carbonates, phosphates, sulfates and sulfides, arsenates, silica, chlorides, fluorides, oxides, hydroxides and Fe-Mn-oxides are known to be produced by biomineralization (Skinner, 2005). Phosphates are the main class beside iron oxides and represent about $25 \%$ of the biogenic minerals usually formed in a biologically controlled fashion. Exceptions are struvite and brushite, which are known to be formed biologically induced (Konhauser and Riding, 2012; Weiner and Dove, 2003). Struvite is a well-known (bio)mineral occurring in human urinary sediments and as kidney stones with a nominal composition $\mathrm{MgNH}_{4} \mathrm{PO}_{4} \cdot 6 \mathrm{H}_{2} \mathrm{O}$ (Le Corre et al., 2007a; Stefov et al., 2005; Lee et al., 2003). It shows a high potential for industrial use since phosphate and ammonia can be precipitated from wastewaters (Le Corre et al., 2007a; Lee et al., 2003; Kofina and Koutsoukos, 2005). The solubility of struvite is known to be slight in water $\left(0.2 \mathrm{~g} \mathrm{~L}^{-1}\right.$ in water), although it is known to be entirely citrate-soluble (Hesse et al., 1989).

The influence of microorganisms on struvite mineralization was tested in a number of studies (Rivadeneyra et al., 1992; Kamnev et al., 1999; Stefov et al., 2005; Ben Omar et al., 1998; Da Silva et al., 2000).These works showed that $58.3 \%$ of the tested bacteria isolated from soil and fresh water were able to produce struvite, including strains of the genera Acinetobacter, Arthrobacter, Bacillus, Corynebacterium, Kurthia, Staphylococcus, Desulfovibrio, Listeria, Proteus, Yersinia, Escherichia (and other members of the family of Enterobacteriaceae), Ureaplasma, Aeromonas, Alcaligenes, Micrococcus,Murraya, Plesiomonas, Myxococcus and Brucella. Struvite biomineralization is suggested to be linked to the release of ammonium from organic matter, either by decomposition of organic material or by urea hydrolysis through microbial urease activity (Rivadeneyra et al., 1999). Other processes have been postulated, because urease-negative bacteria have also been shown to be capable of struvite mineralization. Additionally, some ureasepositive strains did not induce crystallization of struvite, even though high concentrations of ammonia were produced (Rivadeneyra et al., 1999, 1990).

An important biogeochemical factor influencing struvite formation is $\mathrm{pH}$, with struvite formation between $\mathrm{pH} 5$ and 9.5, increasing above pH 8.8 (Doyle et al., 2000; PérezGarcía et al., 1989; Prywer and Torzewska, 2009; Da Silva et al., 2000). In a pilot-scale reactor experiment, small variations of $\mathrm{pH}$, concentration of $\mathrm{Mg}$ or $\mathrm{Ca}$, and the retention time had a significant impact on struvite crystal characteristics and/or production (Le Corre et al., 2007b). $\mathrm{CO}_{2}$ degassing suppressed struvite biomineralization (Saidou et al., 2009).

A new phase isostructural with struvite, in which $\mathrm{Mg}$ is replaced by $\mathrm{Ni}$ (although $\mathrm{Mg}$ had been present in the media), has been reported to be formed by heavy metal-resistant Streptomyces acidiscabies E13 (Haferburg et al., 2008). This phase has a nominal composition $\left(\mathrm{NH}_{4}\right) \mathrm{Ni}\left(\mathrm{PO}_{4}\right)^{\cdot} 6 \mathrm{H}_{2} \mathrm{O}$ and had prior to this study been known only from technical production.

Although intracellular binding of nickel to polyphosphate bodies is reported for Staphylococcus aureus (Gonzalez and Jensen, 1998), no further biomineralization of nickel phosphates is described in the literature. However, microbially enhanced chemisorption of heavy metals into pre-existing minerals has been reported for $\mathrm{Ni}$ (Basnakova et al., 1998).

In comparison to uncontaminated soils, heavy metalcontaminated soils show evidence for prevalence of Grampositives (Schütze and Kothe, 2012). Thus, streptomycetes were investigated to study biomineralization in soils to understand the processes involved, as well as the ecological relevance of mineral formation, in treatments mimicking subnatural to natural conditions. To our knowledge, natural and artificial soil extract was used in one example so far to determine calcite biomineralization in vitro (Párraga et al., 2004). Hence, our approach leads to a deeper insight into natural conditions under which different minerals can be formed.

\section{Material and methods}

\subsection{Strains and growth of bacteria}

Extremely heavy metal-resistant streptomycetes (Schmidt et al., 2008) isolated from the former uranium mining site WISMUT, Ronneburg, Germany, were used for biomineralization experiments on heavy metal-supplemented media, soil agar and directly in soil from different sampling sites.

S. chromofuscus $\mathrm{P} 10 \mathrm{~A}-4$, S. mirabilis $\mathrm{P} 10 \mathrm{~A}-3$, S. mirabilis K7A-1, S. prunicolor P6A-1, S. naganishii P9A-1, S. mirabilis P16B-1, S. chromofuscus P4B-1, S. acidiscabies E13 and heavy metal-sensitive control strain S. lividans TK23 were cultured on agar plates containing oatmeal media (20 g oatmeal, $2 \mathrm{~g}$ glucose, $1.8 \%$ agar) for spore production. Spore suspensions were harvested after 7 days of growth at $28^{\circ} \mathrm{C}$ and purified by filtration through absorbent cotton using distilled water (Kieser et al., 2000). CFU was determined on actinomycete minimal (AM) medium (Schmidt et al., 2008). For preparation of dead biomass (control), AM or TSB medium (tryptic soy broth, Bacto) in $100 \mathrm{~mL}$ test tubes were inoculated and incubated 7 days at $28^{\circ} \mathrm{C}$. Culture aeration started $48 \mathrm{~h}$ after inoculation by shaking at $160 \mathrm{rpm}$. The mycelium was harvested $\left(4000 \mathrm{rpm}, 4^{\circ} \mathrm{C}, 30 \mathrm{~min}\right.$, Megafuge 1.OR Heraeus), washed with distilled water, and autoclaved.

\subsection{Soil samples and analysis of soil}

The soils used for these experiments were a noncontaminated control (C), contaminated test field soil (M1) and a highly contaminated soil from a creek bank (M2). Heavy metal-contaminated soil samples were collected at the former uranium mining site WISMUT, Ronneburg, Germany, from our test field (M1) area and sample site K7 (M2) from the bank of the creek Gessenbach 
(Schmidt et al., 2005). Control soil was taken from a central park, "Paradies" (C), Jena, Germany (GPS 44709773, GK 5642870). All soil was dried at $30^{\circ} \mathrm{C}$ and sieved to a maximum grain size of $2 \mathrm{~mm}$.

For the determination of water holding capacity (WHC), $100 \mathrm{~g}$ of soil was transferred into a glass drip and dowsed with $100 \mathrm{~mL}$ of distilled water. After $24 \mathrm{~h}$, the discharge was quantified and WHC was calculated. Sequential extraction was performed to assess the bioavailable fractions of mobile (F1) and specifically adsorbed (F2) metals (Zeien and Brümmer, 1989) using ICP-MS/ICP-OES (XSeries II, ThermoFisher Scientific, Bremen, Germany) and /ICP-OES (725 ES, Varian, Darmstadt, Germany).

For carbon $(\mathrm{C})$, nitrogen $(\mathrm{N})$ and sulfur $(\mathrm{S})$ contents, soil was ground to a maximum grain size of $<63 \mu \mathrm{m}$. From each sample, $20 \mathrm{mg}$ were transferred into tin capsules and mixed with tungsten trioxide. Analysis was performed using VarioEL (version F, ElementarAnalysesysteme $\mathrm{GmbH}$ ) with sulfanilic acid $\left(5 \mathrm{mg}\right.$, without $\mathrm{WO}_{3}, \mathrm{C} 41.61 \%, \mathrm{~N} 8.09 \%, \mathrm{H}$ $4.07 \%$, S $18.51 \%, \mathrm{O} 27.71 \%$ ) and $\mathrm{T} 100$ (beech tree leaves: $28.5 \mathrm{mg}$, with $\mathrm{WO}_{3}, \mathrm{C} 50.30 \%, \mathrm{~N} 2.629 \%, \mathrm{H} 6.335 \%, \mathrm{~S}$ $0.269 \%$ ) as standards.

\subsection{Biomineralization experiments and characterization of minerals}

Biomineralization experiments were performed under artificial, sub-natural and natural conditions on metal supplemented media (MSM), soil agar (SA) and nutrient-enriched soil (NES). Nutrient supply resulted from addition of AM or TSB.

For biomineralization under artificial conditions, metalsupplemented media (MSM) were used. Stock solutions of metals (sterilized by filtration) were added to the autoclaved media to final concentrations of $30 \mathrm{mM} \mathrm{NiSO}_{4}, 1 \mathrm{mM}$ $\mathrm{CuSO}_{4}, 20 \mathrm{mM} \mathrm{MnCl} 2,1 \mathrm{mM} \mathrm{AlCl}{ }_{3}$ and $20 \mathrm{mM} \mathrm{ZnSO} 4$, mimicking the natural conditions at the metal contaminated test site. Petri dishes were inoculated in duplicates with 5 droplets of $3 \mu \mathrm{L}$ spore suspension per strain. As a control, dead biomass was used in addition to plates not inoculated. All treatments were performed in triplicates.

To mimic subnatural and natural conditions, soil agar (SA content: 1:1, 1:5, 1:10; (Schmidt et al., 2008)) and nutrient-enriched soil (NES prepared from $100 \mathrm{~g}$ autoclaved soil containing $1 \mathrm{ml}$ media per gram soil $(\mathrm{C}, \mathrm{M} 1, \mathrm{M} 2)$ at final WHC of $50 \%$ ) were used. Control plates were prepared without the addition of any media components. Soil and soil agar was inoculated in plates in duplicates with 5 droplets of $3 \mu \mathrm{L}$ spore suspension per strain, sealed with parafilm to avoid desiccation, and incubated at $28^{\circ} \mathrm{C}$ for 56 days (MSM, SA) and 70 days (NES).

Microphotographs and semi-quantitative chemical analyses were acquired with a scanning electron microscopes (SEM)LEO-1450 VP/ Oxford-Link Isis or Zeiss Ultra Plus with a built-in energy-dispersive $\mathrm{X}$-ray spectrometer. The ac- celeration voltage was $20 \mathrm{kV}$ and the observations were done on air-dried cultures after carbon coating. Electron microprobe analyses (EMPA) were done with a Cameca SX50 instrument with an acceleration voltage of $20 \mathrm{kV}$ and beam current of $20 \mathrm{nA}$. The cultures were dried at $80^{\circ} \mathrm{C}$, fixed on glass slides by self-adhesive labels, coated with carbon and analyzed. Crystal structure of the biominerals was investigated with an X-ray diffractometer Bruker AXS D8 Advance, employing $\mathrm{Cu}$ Ka radiation. The samples were powdered and smeared onto a zero-background silicon sample holder and scanned in the angular range of $5-80^{\circ} 2 \theta$, step size of $0.01^{\circ}$ $2 \theta$ and dwell time of $2 \mathrm{~s}$.

\subsection{Microbial processes influencing geochemical parameters}

Ammonification (colorimetrically using universal indicator: Unitest) and $\mathrm{pH}$ changes of the media (via $\mathrm{pH}$ probe (noLab pH 720, WTW)) were verified in liquid cultures after 10 days of growth at $28^{\circ} \mathrm{C}$ and $160 \mathrm{rpm}$ or on indicator plates containing $0.05 \mathrm{~g}$ bromothymol blue or $0.025 \mathrm{~g}$ methyl red per liter of media. Urease production was measured (Bioassay Systems) for extracellular (supernatant) and intracellular (crude extract of mycelium ground in liquid nitrogen, dissolved in sodium phosphate buffer $50 \mathrm{mM}, \mathrm{pH} 7.8$, centrifugation $11000 \mathrm{rpm}, 4^{\circ} \mathrm{C}, 20 \mathrm{~min}$, Hettich) activity in AM media to mimic nutrient-poor conditions.

\section{Results}

\subsection{Growth and crystal production under artificial conditions}

All tested strains were able to grow on rich TSB and depleted mineral AM media. Addition of metal salts to AM medium suppressed growth of the sensitive control strain $S$. lividans TK23, but also some of the heavy metal-resistant isolates (Table 1). TSB supported growth with metal addition, even with the metal-sensitive strain, in three of the five metals tested: $\mathrm{Cu}, \mathrm{Al}$ and $\mathrm{Mn}$. At least one metal at the concentration was tolerated in AM by each of the metal-resistant isolates, and with growth on AM with up to 4 of the 5 metals tested being observed with multi-metal resistant $S$. mirabilis P16B-1. For heavy metal-supplemented plates, three different kinds of minerals could be detected: struvite on TSB without metal addition or with $\mathrm{Al}, \mathrm{Cu}$ or $\mathrm{Mn}$ in all cases; nickel hydrogen phosphate was produced on nickel containing TSB by 6 of the metal resistant isolates; and switzerite $\left(\mathrm{Mn}_{3}\left(\mathrm{PO}_{4}\right)_{2} \cdot 7 \mathrm{H}_{2} \mathrm{O}\right)$ was found on AM plates containing $\mathrm{Mn}$ for 4 strains (Fig. 1).

The morphology of struvite was variable (Fig. 1a-f; Table 2) for different strains; biomineralization occurred not only on the colony surface, but also in the media close to the colony. The most common habitus of struvite is acicular, but the products also included radial aggregates of acicular 
Table 1. Growth and biomineralization under artificial conditions. The strains were grown on plates containing the indicated heavy metal for 56 days $(n=3)$.

\begin{tabular}{|c|c|c|c|c|c|c|c|c|c|c|c|c|c|}
\hline \multirow[b]{2}{*}{ genus } & \multirow[b]{2}{*}{ strain } & \multicolumn{2}{|c|}{ control } & \multicolumn{2}{|c|}{$\begin{array}{c}\mathrm{AlCl}_{3} \\
{[1 \mathrm{mM}]}\end{array}$} & \multicolumn{2}{|c|}{$\begin{array}{c}\mathrm{CuSO}_{4} \\
{[1 \mathrm{mM}]}\end{array}$} & \multicolumn{2}{|c|}{$\begin{array}{c}\mathrm{MnCl}_{2} \\
{[20 \mathrm{mM}]}\end{array}$} & \multicolumn{2}{|c|}{$\begin{array}{c}\mathrm{NiSO}_{4} \\
{[30 \mathrm{mM}]}\end{array}$} & \multicolumn{2}{|c|}{$\begin{array}{c}\mathrm{ZnSO}_{4} \\
{[20 \mathrm{mM}]}\end{array}$} \\
\hline & & TSB & $\mathrm{AM}$ & TSB & $\mathrm{AM}$ & TSB & $\mathrm{AM}$ & TSB & $\mathrm{AM}$ & TSB & $\mathrm{AM}$ & TSB & $\mathrm{AM}$ \\
\hline S. lividans & TK23 & 1 & 0 & 1 & n.g.* & 1 & n.g. & 1 & n.g. & n.g. & n.g. & n.g. & n.g. \\
\hline S. acidiscabies & E13 & 1 & 0 & 1 & n.g. & 1 & n.g. & 1 & 2 & n.g. & n.g. & n.g. & n.g. \\
\hline \multirow[t]{2}{*}{ S. chromofuscus } & P10A-4 & 1 & 0 & 1 & n.g. & 1 & n.g. & 1 & 2 & 3 & 0 & n.g. & n.g. \\
\hline & P4B-1 & 1 & 0 & 1 & n.g. & 1 & n.g. & 1 & 0 & 0 & 0 & 0 & 0 \\
\hline \multirow[t]{3}{*}{ S. mirabilis } & K7A-1 & 1 & 0 & 1 & n.g. & 1 & n.g. & 1 & 2 & 3 & 0 & n.g. & 0 \\
\hline & P10A-3 & 1 & 0 & 1 & n.g. & 1 & n.g. & 1 & 0 & 3 & 0 & n.g. & 0 \\
\hline & P16B-1 & 1 & 0 & 1 & 0 & 1 & n.g. & 1 & 0 & 3 & 0 & 0 & 0 \\
\hline S. naganishii & P9A-1 & 1 & 0 & 1 & n.g. & 1 & n.g. & 1 & 2 & 3 & 0 & 0 & 0 \\
\hline S. prunicolor & P6A-1 & 1 & 0 & 1 & n.g. & 1 & n.g. & 1 & 0 & 3 & 0 & 0 & 0 \\
\hline
\end{tabular}

biominerals: 1: struvite; 2 : switzerite; 3 : nickel hydrogen phosphate; 0: no crytsals. *n.g. = no growth
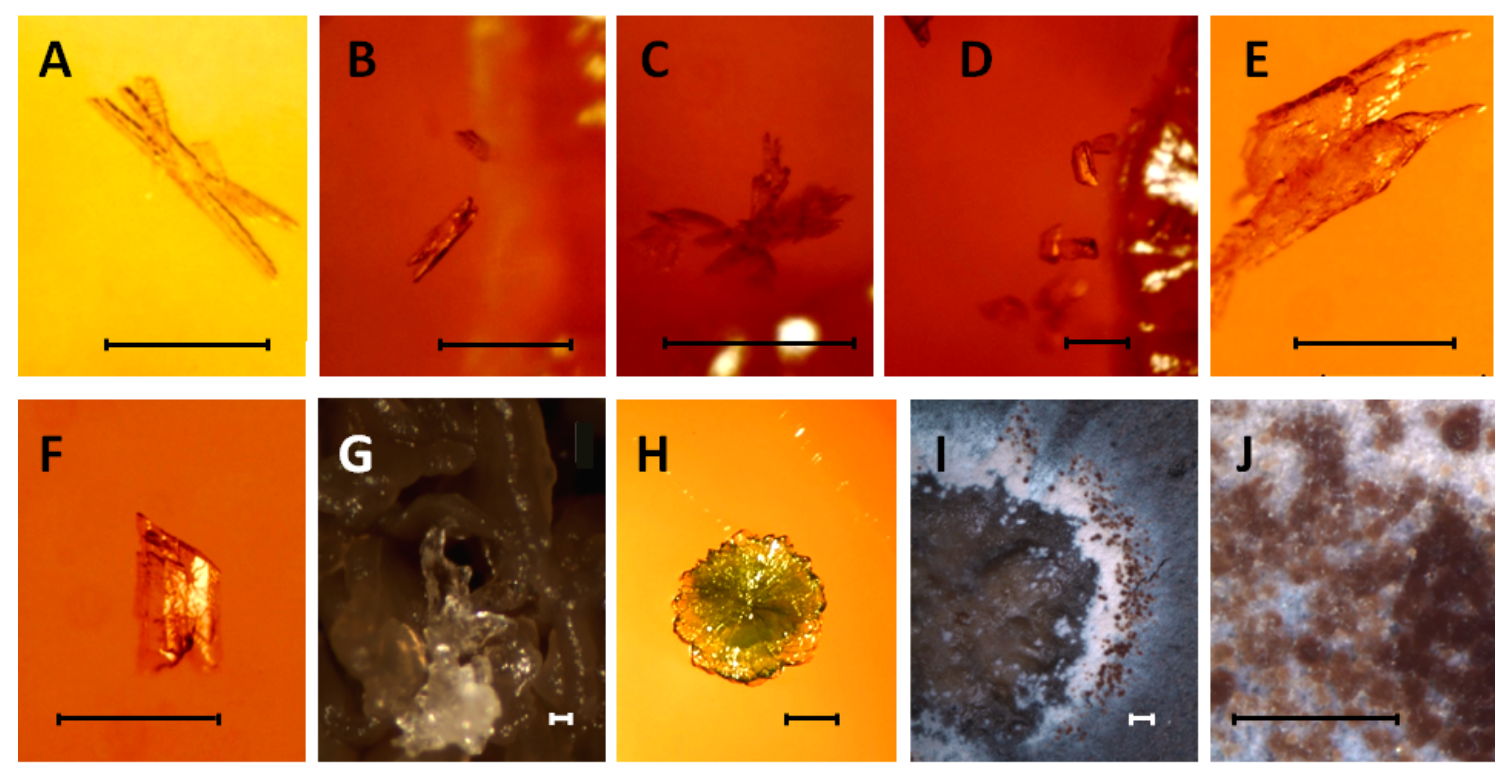

Fig. 1. Crystals mineralized in the presence of streptomycetes: asymmetric macroscopic structures of struvite (A-F) near colonies of $S$. mirabilis P16A-1 (A-C) and S. acidiscabiesE13 (D-F); encrusted mycelium of S. acidiscabiesE13 (G), nickel hydrogen phosphate (hydrated) of S. chromofuscus P10A-4 (H); switzerite crystals of S. acidiscabiesE13 (I-J); bars, 0.5 mm.

crystals, platy crystals with a wedge-like outline, parallel intergrowths of subhedral crystals, or fine-grained aggregates (Table 2). Switzerite occurred as fine-grained aggregates devoid of crystal forms.

\subsection{Establishing conditions for sub-natural to natural conditions for biomineralization}

To mimic field conditions, but still being easy to manipulate conditions, soil agar plates were chosen. In order to simulate natural conditions even better, soils were used directly, without the addition of agar, but instead adding nutrient solution to allow for better growth of the streptomycetes inoculated in the soil.

The soils used for these experiments were the noncontaminated control (C), contaminated test field soil (M1), and a highly contaminated soil from a creek bank (M2). The elemental analyses for these soils revealed that, albeit higher in bioavailable metal concentration (Fig. 2), M2 soil was intermediate in respect to $\mathrm{C}$ and $\mathrm{N}$ contents, while the test field soil was extremely deprived in carbon, nitrogen and sulfur (Table 3). In addition, phosphate was under detection limit in all soils for both mobile and specifically adsorbed fractions, while potassium and sodium were below detection limit in the specifically adsorbed fractions with 
Table 2. Appearance of struvite crystal on TSB spiked with $1 \mathrm{mM}$ metal salt.

\begin{tabular}{|c|c|c|c|}
\hline genus & strain & $\mathrm{AlCl}_{3}$ & $\mathrm{CuSO}_{4}$ \\
\hline S. lividans & TK23 & $\begin{array}{l}\text { radial aggregates of acicular } \\
\text { crystals }\end{array}$ & no defined shape \\
\hline S. acidiscabies & E13 & $\begin{array}{l}\text { Acicular; grains, } \\
\text { partly acicular }\end{array}$ & no defined shape \\
\hline \multirow[t]{3}{*}{ S. chromofuscus } & P10A-4 & $\begin{array}{l}\text { close to colony: aggregates of } \\
\text { grains; farther apart: radial } \\
\text { aggregates of acicular crystals }\end{array}$ & no defined shape \\
\hline & P4B-1 & $\begin{array}{l}\text { acicular; near colonies: parallel } \\
\text { intergrowth of subhedral } \\
\text { crystals }\end{array}$ & $\begin{array}{l}\text { acicular, size negative correlated } \\
\text { with distance to colony }\end{array}$ \\
\hline & K7A-1 & $\begin{array}{l}\text { radial aggregates of acicular } \\
\text { crystals; platy crystals with } \\
\text { wedge-like outline; grains; } \\
\text { acicular }\end{array}$ & no defined shape \\
\hline \multirow[t]{2}{*}{ S. mirabilis } & P10A-3 & $\begin{array}{l}\text { at distance: radial aggregates of } \\
\text { acicular crystals, }\end{array}$ & $\begin{array}{l}\text { at distance: radial aggregates of } \\
\text { acicular crystals; aggregates of } \\
\text { grains }\end{array}$ \\
\hline & P16B-1 & $\begin{array}{l}\text { acicular; parallel intergrowth of } \\
\text { subhedral crystals }\end{array}$ & acicular; aggregates of grains \\
\hline S. naganishii & P9A-1 & acicular; grains & $\begin{array}{l}\text { radial aggregates of acicular } \\
\text { crystals; acicular grains; parallel } \\
\text { intergrowth of subhedral crystals }\end{array}$ \\
\hline S. prunicolor & P6A-1 & no defined shape & $\begin{array}{l}\text { parallel intergrowth of subhedral } \\
\text { crystals }\end{array}$ \\
\hline
\end{tabular}

Table 3. CNS analysis of soil samples from contaminated site (M2, M1) and control site (C).

\begin{tabular}{lccc}
\hline & $\mathrm{C}$ & $\mathrm{M} 1$ & $\mathrm{M} 2$ \\
\hline $\mathrm{C}_{\text {total }}[\%]$ & $8.55 \pm 0.18$ & $0.19 \pm 0.03$ & $4.05 \pm 0.005$ \\
$\mathrm{~N}[\%]$ & $0.58 \pm 0.01$ & $0.03 \pm 0.00003$ & $0.26 \pm 0.007$ \\
$\mathrm{~S}[\%]$ & $0.18 \pm 0.004$ & n.d. & $0.17 \pm 0.008$ \\
\hline
\end{tabular}

* not detectable

different contents in the mobile fractions (see supplementary Table S1). Magnesium was present at elevated levels in $\mathrm{C}$ and $\mathrm{M} 2$ with more than $600 \mu \mathrm{g} \mathrm{g}^{-1}$, while approximately $150 \mu \mathrm{g} \mathrm{g}^{-1}$ were found in the nutrient-poor test field soil M1. Values for $\mathrm{Ca}$ and $\mathrm{Mg}$ have been lowest in $\mathrm{M} 1$ soil $(\mathrm{F} 1+\mathrm{F} 2$ : $362 \mu \mathrm{g} \mathrm{Ca} \mathrm{g}^{-1}$ soil, $137 \mu \mathrm{g} \mathrm{Mg} \mathrm{g}^{-1}$ soil) and highest in $\mathrm{C}$ soil $\left(\mathrm{F} 1+\mathrm{F} 2: 12078 \mu \mathrm{g} \mathrm{Cag}^{-1}, 589 \mu \mathrm{g} \mathrm{Mg} \mathrm{g}^{-1}\right.$ soil). As for the heavy metal load, M2 soil clearly showed the highest concentrations with additional contamination of $\mathrm{Cd}\left(0.292 \mu \mathrm{g} \mathrm{g}^{-1}\right.$ mobile), Co (2.391 $\mu \mathrm{g} \mathrm{g}^{-1}$ mobile), and $\mathrm{U}\left(0.152 \mu \mathrm{g} \mathrm{g}^{-1}\right.$ mobile and $171 \mu \mathrm{g} \mathrm{g}^{-1}$ specifically absorbed), while $\mathrm{Fe}$, as well as $\mathrm{Al}$, was highest in $\mathrm{C}$.

\subsection{Growth and crystal production under sub-natural conditions on soil agar (SA)}

Sub-natural conditions were achieved by the use of soil agar with two different amounts of C, M1, or M2 soil at $1: 5$ and $1: 1$ soil contents in either rich TSB or minimal AM medium, respectively. As a control, water agar was used, to which the soil was added. For the highly metal contaminated M2 soil, a third soil concentration of $1: 10$ was included. On all C soil agar plates, all strains grew, albeit without crystals being observed. On M1 and M2, formation of struvite was observed in some samples (Table 4) where mycelium was partly encrusted by struvite (Fig. 1g). Interestingly, small amounts of $\mathrm{Mn}$ were detected in the minerals formed by $S$. mirabilis P16B-1 on M2 soil by element mapping (Fig. 3b). This indicates that other metals can either be incorporated or sorbed to the surface of struvite. In comparison to the laboratory plate assays (MSM), the availability of Ni or Mn did not lead to switzerite or nickel hydrogen phosphate formation.

\subsection{Growth and production of crystals under natural conditions}

To mimic natural conditions most similar to the original environment, soil was used for microcosms with and without addition of media components imitating fertilized soils. Again, all strains were able to grow on $\mathrm{C}$ soil with or without media 
Table 4. Growth and biomineralization under sub-natural conditions on soil agar (SA from M2, M1) after 56 days $(n=3)$.

\begin{tabular}{|c|c|c|c|c|c|c|c|c|c|c|c|c|c|c|c|c|}
\hline \multirow{3}{*}{ genus } & \multicolumn{5}{|c|}{ M1 } & \multicolumn{8}{|c|}{ M2 } & \multirow{2}{*}{\multicolumn{3}{|c|}{ Con }} \\
\hline & strain & \multicolumn{2}{|c|}{ TSB } & \multicolumn{2}{|c|}{$\mathrm{AM}$} & \multicolumn{2}{|c|}{ Con } & \multicolumn{3}{|c|}{ TSB } & \multicolumn{3}{|c|}{$\mathrm{AM}$} & & & \\
\hline & & $a^{*}$ & $\mathrm{~b}$ & $\mathrm{a}$ & $\mathrm{b}$ & $\mathrm{a}$ & $\mathrm{b}$ & $\mathrm{a}$ & $\mathrm{b}$ & $\mathrm{c}$ & $\mathrm{a}$ & $\mathrm{b}$ & $\mathrm{c}$ & $\mathrm{a}$ & $\mathrm{b}$ & $\mathrm{c}$ \\
\hline S. lividans & TK23 & 1 & 1 & 0 & 0 & 0 & 0 & 0 & 0 & 0 & 0 & 0 & n.g. & 0 & 0 & 0 \\
\hline S. acidiscabies & E13 & 1 & 0 & 0 & n.g. & n.g. & n.g. & 0 & 0 & 0 & n.g. & n.g. & n.g. & 0 & n.g. & n.g. \\
\hline S. chromofuscus & P10A-4 & 1 & 0 & n.g. & 0 & n.g. & 0 & 0 & 0 & 0 & 0 & n.g. & 0 & 0 & 0 & 0 \\
\hline & P4B-1 & 1 & 0 & n.g. & 0 & n.g. & 0 & 0 & 0 & 0 & 0 & n.g. & 0 & 0 & 0 & 0 \\
\hline S. mirabilis & K7A-1 & 1 & 1 & n.g. & 0 & n.g. & 0 & 0 & 0 & 0 & 0 & 0 & 0 & 0 & 0 & 0 \\
\hline & P10A-3 & 1 & 1 & n.g. & 0 & n.g. & 0 & 0 & 0 & 0 & 0 & 0 & 0 & 0 & 0 & 0 \\
\hline & P16B-1 & 1 & 1 & n.g. & 0 & n.g. & 0 & 0 & 0 & 0 & 0 & 0 & 0 & 0 & 0 & 0 \\
\hline S. naganishii & P9A-1 & 1 & 1 & 0 & 0 & 0 & 0 & 0 & 0 & 0 & 0 & 0 & 0 & 0 & 0 & 0 \\
\hline S. prunicolor & P6A-1 & 1 & 1 & 0 & 0 & 0 & 0 & 0 & 0 & 0 & 0 & 0 & n.g. & 0 & 0 & 0 \\
\hline S. tendae & $\mathrm{F} 4$ & 0 & 1 & 0 & n.g. & 0 & n.g. & 0 & 0 & 0 & 0 & n.g. & n.g. & 0 & n.g. & n.g. \\
\hline
\end{tabular}

* soil dilution: a, $1: 1 ; \mathrm{b}, 1: 5 ; \mathrm{c}, 1: 10$

n.g.: no growth after 56 days

1: struvite formation; 0 : no crytsals

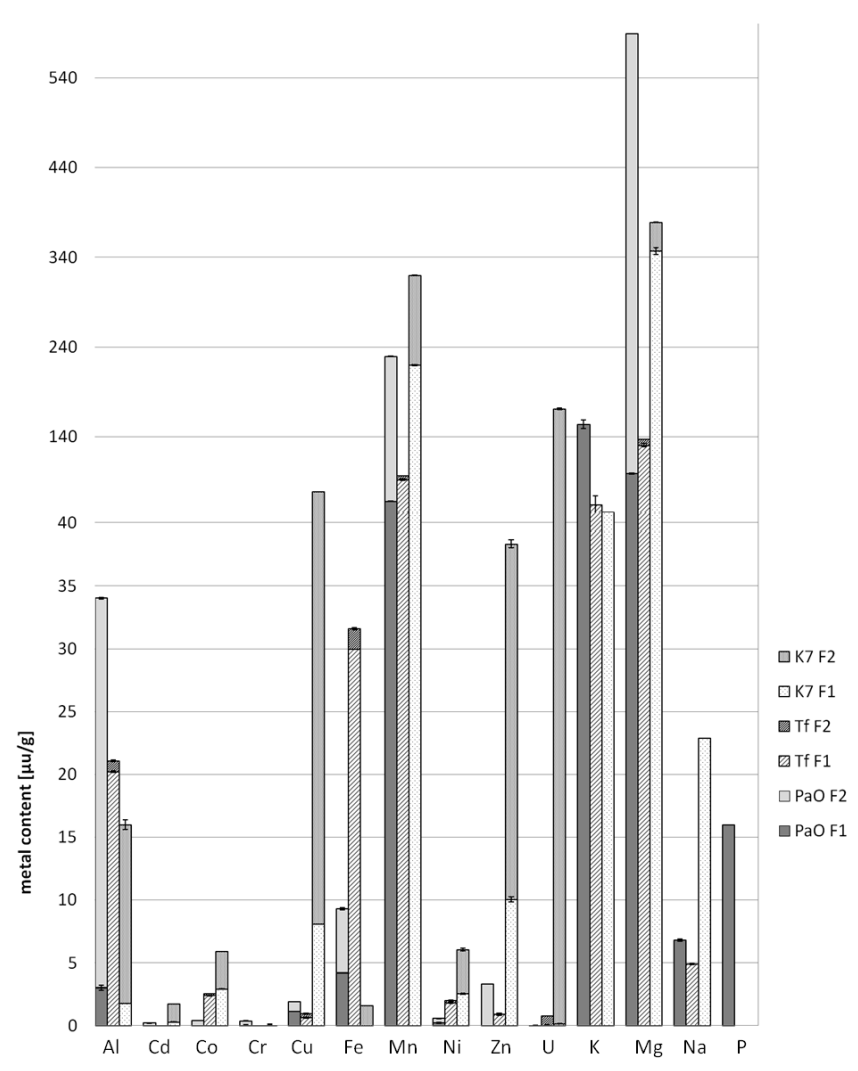

Fig. 2. Available metals and micronutrients $\left[\mu \mathrm{g} \mathrm{g}^{-1}\right.$ soil] of mobile fraction (F1) and specifically adsorbed fraction (F2) from control soil (C) and heavy metal-contaminated soils M1 and M2

components, as well as on TSB supplemented M1 and M2 soil. In general, the bacteria grew better on M2 soil than on M1 soil, most likely linking the higher intrinsic nutrition to growth. Surprisingly, the heavy metal-resistant strains
Table 5. Growth and biomineralization under natural conditions directly in nutrient enriched soil with (M1) or without metal contamination $(\mathrm{C}) ;(n=3)$.

\begin{tabular}{llcc}
\hline genus & strain & C & M1 \\
\hline S. lividans & TK23 & 2 & 1 \\
S. acidiscabies & E13 & 0 & 0 \\
S. chromofuscus & P10A-4 & 0 & 1 \\
& P4B-1 & 0 & 0 \\
S.mirabilis & K7A-1 & 2 & 1 \\
P10A-3 & 1 & 0 \\
S. naganishii & P16B-1 & 1 & 1 \\
P. prunicolor & P6A-1 & 0 & 1 \\
biominerals: 1: struvite; 2: switzerite; 0: no crystals
\end{tabular}

grew better on M2 soil without addition of any media components than on media-supplemented soil, which might indicate that the addition of mineral nutrient elements might lead to salt stress in the highly contaminated soil. Struvite and switzerite (Fig. 1i-j) were obtained from some of these nutrient-enriched soil microcosms (Table 5) on soil amended with complex TSB medium. No crystal formation was observed if minimal medium had been added, and only in one case with water added to the contaminated soil, was struvite mineralization found (S. mirabilis K7A-1).

\subsection{Investigation of potential mechanisms for biomineralization}

To determine factors involved in biologically induced mineral formation, $\mathrm{pH}$ changes, ammonification and urease activity were tested. The sensitivity of biomineralization to $\mathrm{pH}$ allows for bacterial control of biomineralization due to ammonification, a process provided by urease activity. The 

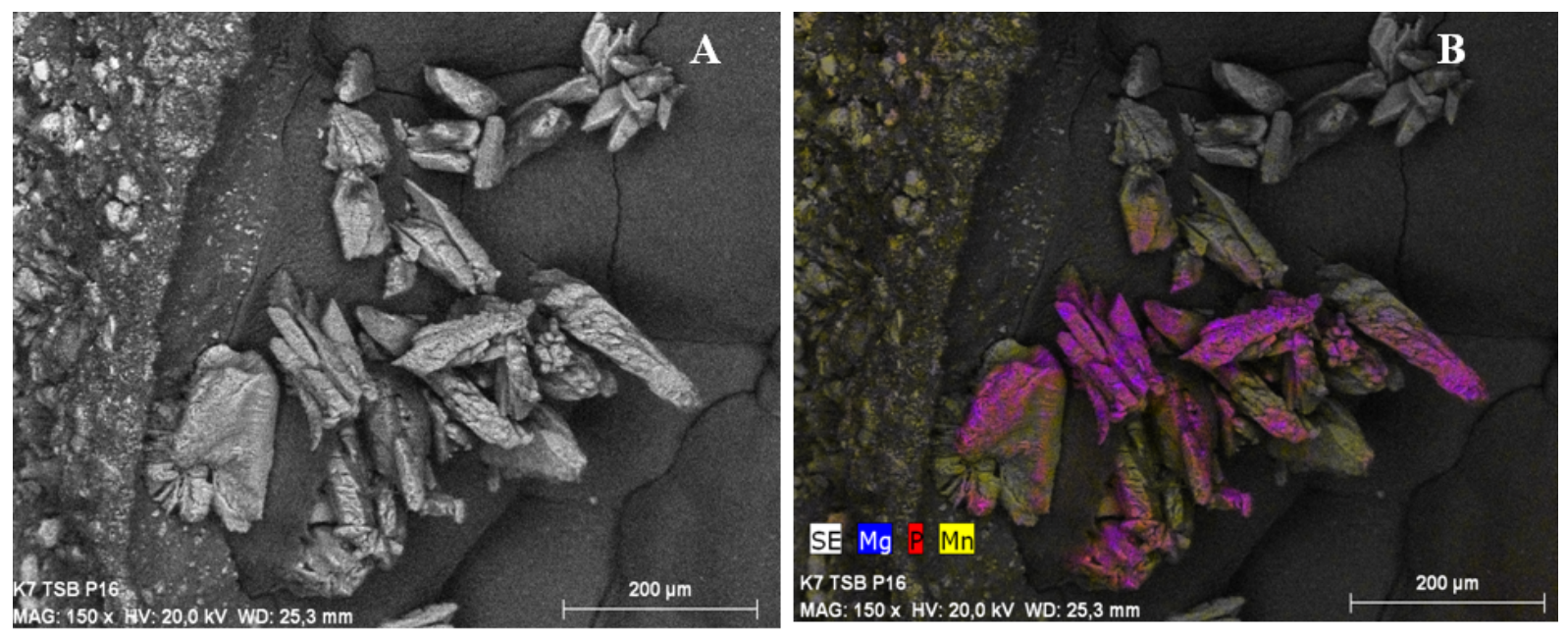

Fig. 3. Struvite crystals on the colony surface of S. mirabilis P16B-1: back scatter image (A); corresponding element mapping (B): blue, Mg; red, $\mathrm{P}$; yellow, $\mathrm{Mn}$; derived color, elements corresponding to respective fast colors.

shift of $\mathrm{pH}$ varied, with both positive and negative shifts in a wide range. On TSB media however, changes to alkaline conditions occurring could be detected. Ammonification for at least two $\mathrm{pH}$ units were observed with $S$. chromofuscus P10A-4, S. mirabilis P10A-3 and P16B-1 (but not with the third strain of this species, P16A-1) and with S. naganishii P9A-1. Acidification was found to be associated with growth on AM. Using indicator plates, diffusion of the acids produced on AM could be shown, which leads to a diffusion gradient in physico-chemical conditions linked to the bacterial metabolism (Fig. 4a). For TSB containing indicator plates, neutral to slightly alkaline $\mathrm{pH}$ in a close vicinity to the colony could be shown (Fig. 4b). Thus, alteration of $\mathrm{pH}$ strongly depends on media components, their buffer capacity and excreted metabolites. Ammonification could be revealed in liquid TSB medium for the tested strains, while liquid AM medium did not allow for ammonium formation. Hence, urease excretion was tested with AM grown cells. As a control, intracellular urease levels were also determined. Both intracellular and extracellular urease activity was shown for all tested strains (Fig. 5).

\section{Discussion}

Bacteria can contribute actively to geological processes in biogeochemical cycling, metal mobility, mineral transformation, decomposition, bioweathering, and soil and sediment formation (Gadd, 2010; Cappellen, 2003). With respect to heavy metal-containing soils, resistance is a prerequisite for survival and contribution to biogeochemical processes. The strains $S$. chromofuscus $\mathrm{P} 10 \mathrm{~A}-4$ and P4B1, S. mirabilis K7A-1, P10A-3 and P16B-1, S. naganishii P9A-1 and $S$. prunicolor P6A-1 were previously tested for their metal resistance on minimal media containing differ- ent concentration of $\mathrm{NiCl}_{2}, \mathrm{NiSO}_{4}, \mathrm{AlCl}_{3}, \mathrm{CdCl}_{2}, \mathrm{CoCl}_{2}$, $\mathrm{CuSO}_{4}$ and $\mathrm{ZnSO}_{4}$ (Schmidt et al., 2008). Here, we could show that all strains were able to form biominerals, and that media influenced crystal formation. Indeed, all tested strains induced struvite formation under certain conditions, and two other, formerly undetected streptomycete biominerals, namely switzerite and nickel hydrogen phosphate could be produced on metal-spiked plates. The formation of another phosphate-containing mineral, Ni-struvite, had been reported before for S. acidiscabies E13 (Haferburg et al., 2008). In that case, however, $\mathrm{NiCl}_{2}$ was used instead of the sulfate, which might have resulted in conditions favoring the $\mathrm{Ni}$-struvite precipitation.

The struvite crystals formed differed in macroscopic appearance, which has been described earlier for struvite biominerals with shapes from planar, X-shaped (McLean et al., 1991; hemimorphic, coffin-lid, twining; Prywer and Torzewska, 2010), to complex superstructures like tetragonal bipyramids or prismatic structures (Chen et al., 2010). Time, and especially $\mathrm{pH}$, have been reported to exert a major impact on resulting crystal shapes (Chen et al., 2010; Prywer and Torzewska, 2010, 2009). In addition, for the synthetic production of struvite, it could be shown that the morphology of the crystals was influenced by the initial concentration of $\mathrm{Mg}$ in solution, with increasing $\mathrm{Mg}$ concentrations leading to more frequent orthorhombic shapes and bigger size of the crystals. Ca ions also showed a significant impact on size, shape and purity of the product recovered (Le Corre et al., 2005), which is of importance specifically in our trials where the soils contained different concentrations of $\mathrm{Ca}$ as well as other metals. The $\mathrm{Mg}$ contents led to $\mathrm{Ca} / \mathrm{Mg}$ ratios of 2.6 : 1 for M1 soil, $6.4: 1$ for M2 soil and $20: 1$ for C soil. It has been shown by (Le Corre et al., 2005) that increasing $\mathrm{Ca}$ concentration reduced the crystal size and also inhibited struvite formation at high Ca loads. In these laboratory-based 

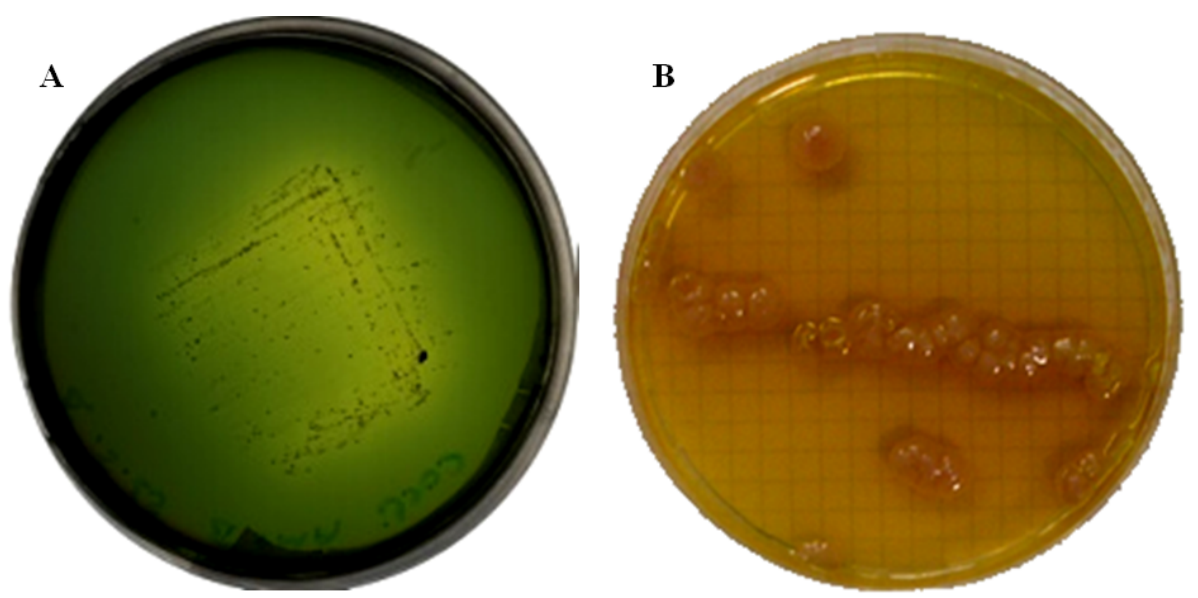

Fig. 4. Indicator plates display $\mathrm{pH}$ gradient due to bacterial inoculation after 7 days of growth: S. lividansTK23 on AM medium containing bromothymol blue (A), neutral pH: green, acidic $\mathrm{pH}$ : yellow; S. naganishii P9A-1 on TSB medium containing methyl red (B), neutral pH: yellow, basic $\mathrm{pH}$ : orange.

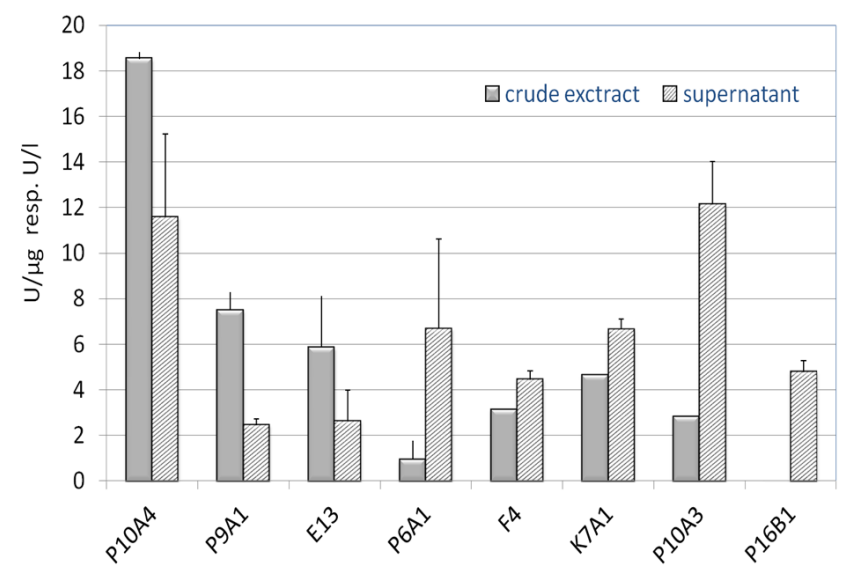

Fig. 5. Urease activity $\left[\mathrm{UL}^{-1}\right]$ in supernatant and specific activity $\left[\mathrm{U}_{\mu \mathrm{g}}{ }^{-1}\right]$ in crude extract

investigations, it has been found that $\mathrm{Ca} / \mathrm{Mg}$ ratios of less than 1 inhibited struvite formation and favored formation of amorphous calcium phosphate instead (Le Corre et al., 2005). The high $\mathrm{Ca} / \mathrm{Mg}$ ratios up to $20: 1$ and the fact that struvite was formed nevertheless indicate that in soil, biomineralization of struvite is influenced by other parameters, most likely depending on the bacterial activities in our inoculated samples.

In one instance, manganese incorporation or adsorption to struvite could be shown. The same effect has been published for metal addition to stored urine, which resulted in co-precipitation of $\mathrm{Cd}, \mathrm{Cu}$ and $\mathrm{Pb}$ with switzerite, while $\mathrm{Co}$, $\mathrm{Cr}$ and $\mathrm{Ni}$ as well as As were not incorporated (Ronteltap et al., 2007). Urease activity was detected both intracellularly and excreted. Since the presence of urea is unlikely in soil without the addition of manure, the induction of enzyme expression is likely dependent on other inducers not yet known.
In accordance to struvite biomineralization having been suggested to be linked to the release of ammonium from organic matter by decomposition of organic material through microbial urease activity (Rivadeneyra et al., 1999), urease activity could be shown to be correlated to organic $\mathrm{C}$, total $\mathrm{N}$ and cation exchange capacity. In addition, clay showed a weak positive correlation, while with sand, a negative correlation has been observed. No correlation was shown for $\mathrm{pH}$, silt or $\mathrm{CaCO}_{3}$ presence (Zantua et al., 1977). We could show that urease is also expressed in minimal medium, indicating a broader spectrum of inducers for the enzyme and potentially wider substrate spectra linked to a possible role for biomineralization in natural soils.

We also could detect switzerite, a Mn-Fe phosphate (Fanfani and Zanazzi, 1979; Yakubovich et al., 2003), which in our case contained only Mn despite the presence of $\mathrm{Fe}$ in the media. Switzerite had been reported to be formed in the presence of the Gram-negative bacterium Shewanella oneidensis MR-1 under Fe(III)-reducing conditions, but with unknown genesis (Reardon et al., 2010). Here, we found several Gram-positive streptomycetes to be able to biomineralize switzerite. The role of the bacteria in formation of the mineral is evident from the finding that in all our assays, minerals were never formed on non-inoculated media or at larger distances from the colonies.

The green radial aggregates on TSB media spiked with $\mathrm{NiSO}_{4}$ were identified as hydrated nickel hydrogen phosphate with the chemical formula $\mathrm{Ni}\left(\mathrm{H}_{2} \mathrm{O}\right)_{6} \mathrm{HPO}_{4} \cdot \mathrm{H}_{2} \mathrm{O}$. The crystal structure of hexa-aqua-nickel(II) hydrogen phosphate monohydrate was published by Wang et al. (2005) after the addition of $\mathrm{Ni}\left(\mathrm{ClO}_{4}\right)_{2} \cdot \mathrm{H}_{2} \mathrm{O}$ to an aqueous solution of ophospho-L-serine. However, no biomineralization has been reported so far.

In this study, we have used sub-natural to natural conditions rather than soil extract to detect biominerals. It seems 
noteworthy that all three biominerals, all new at least for the genus Streptomyces (which is dominant in our metal contaminated soil; (Schütze and Kothe, 2012)), were phosphates. In case of struvite precipitation, an external storage of $\mathrm{P}$ may be coupled to metal detoxification. Struvite has a very slight solubility in water of about $160 \mathrm{mg} \mathrm{L}^{-1}$ at $25^{\circ} \mathrm{C}$ (Bhuiyan et al., 2007; Ohlinger et al., 1998; Kim et al., 2007). Since struvite is well soluble in an acidic environment (Hutnik et al., 2011) and streptomycetes are able to excrete acidic secondary metabolites (Bibb, 2005), they easily can (re)solubilize struvite, which is faster than for other phosphate minerals (Roncal-Herrero and Oelkers, 2011). Thus, the bacteria have used nutrients to be able to precipitate metals by formation of biominerals which might be associates with metal resistance.

This study first showed biomineralization directly in soil and could show that streptomycetes are able to mineralize struvite independent of their metal resistance, whereas only heavy metal-resistant streptomycetes have been involved in formation of switzerite and nickel hydrogen phosphate. Switzerite precipitation is first reported for the genus Streptomyces. For mechanisms of biomineralization, in case of struvite, the excretion of secondary metabolites, $\mathrm{pH}$ changesinduced and urease activity can be proposed as a potential benefit through remobilization and use of $\mathrm{P}, \mathrm{N}$ and $\mathrm{Mg}$. These findings may help to interpret the role of Streptomyces-induced biomineralization and offer an explanation for biomineral formation in soil.

\section{Supplementary material related to this article is available online at: http://www.biogeosciences.net/10/ 3605/2013/bg-10-3605-2013-supplement.pdf.}

Acknowledgements. We would like to thank HIGRADE and BMBF for funding, as well as JSMC and DFG-Gk1257 for support. Maria Wierzbicka-Wieczorek and Michael Abratis, Mineralogy, are thanked for their introduction to EDX and XRR analysis. We also gratefully acknowledge the advice of Matthias Kästner from Environmental Biotechnology, Helmholtz Centre for Environmental Research - UFZ, Leipzig, Germany.

Edited by: E. J. Javaux

\section{References}

Adele, L. B.: Biomineralization: Conflicts, challenges, and opportunities, J. Cell. Biochem., 72, 83-91, 1998.

Basnakova, G., Spencer, A. J., Palsgard, E., Grime, G. W., and Macaskie, L. E.: Identification of the Nickel Uranyl Phosphate Deposits on Citrobacter sp. Cells by Electron Microscopy with Electron Probe X-ray Microanalysis and by Proton-Induced Xray Emission Analysis, Environ. Sci. Technol., 32, 760-765, 1998.
Ben Omar, N., Gonzalez-Munoz, M. T., and Penalver, J. M. A.: Struvite crystallization on Myxococcus cells, Chemosphere, 36, 475-481, 1998.

Bhuiyan, M. I., Mavinic, D. S., and Beckie, R. D.: A solubility and thermodynamic study of struvite, Environ. Technol., 28, 10151026, 2007.

Bibb, M. J.: Regulation of secondary metabolism in streptomycetes, Curr. Opin. Microbiol., 8, 208-215, 2005.

Cappellen, P. V.: Biomineralization and Global Biogeochemical Cycles, in: Biomineralization, edited by: Dove, P. M., Yoreo, J. J. D., and Weiner, S., Biogeochemistry of Earth Processes - Reviews in Mineralogy and Geochemistry, 2003.

Chen, L., Shen, Y. H., Xie, A. J., Huang, F. Z., Zhang, W. Q., and Liu, S. X.: Seed-Mediated Synthesis of Unusual Struvite Hierarchical Superstructures Using Bacterium, Crystal Growth Des., 10, 2073-2082, 2010.

Da Silva, S., Bernet, N., Delgenès, J. P., and Moletta, R.: Effect of culture conditions on the formation of struvite by Myxococcus xanthus, Chemosphere, 40, 1289-1296, 2000.

Doyle, J. D., Philp, R., Churchley, J., and Parsons, S. A.: Analysis of Struvite Precipitation in Real and Synthetic Liquors, Process Saf. Environ., 78, 480-488, 2000.

Fanfani, L. and Zanazzi, P. F.: Switzerite - Its Chemical Formula and Crystal-Structure, Miner. Petrol., 26, 255-269, 1979.

Gadd, G. M.: Metals, minerals and microbes: geomicrobiology and bioremediation, J. Med. Microbiol., 156, 609-643, 2010.

Gonzalez, H. and Jensen, T. E.: Nickel sequestering by polyphosphate bodies in Staphylococcus aureus, Microbios, 93, 179-185, 1998.

Haferburg, G., Kloess, G., Schmitz, W., and Kothe, E.: "Ni-struvite" - A new biomineral formed by a nickel resistant Streptomyces acidiscabies, Chemosphere, 72, 517-523, 2008.

Hesse, A., Schreyger, F., Tuschewitzki, G. J., Classen, A., and Bach, D.: Experimental investigations on dissolution of incrustations on the surface of catheters, Urol. Int., 44, 364-369, 1989.

Hutnik, N., Wierzbowska, B., Piotrowski, K., and Matynia, A.: Continuous reaction crystallization of struvite from solution containing phosphate(V) and nitrate(V) ions, The Online J. Sci. Technol., 3, 58-66, 2011.

Kamnev, A. A., Antonyuk, L. P., Colina, M., Cherynshev, A. V., and Ignatov, V. V.: Investigation of a microbially produced structural modification of magnesium-ammonium orthophosphate, Monatsh. Chem., 130, 1431-1442, 1999.

Kieser, T., Bibb, M. J., Buttner, M. J., Chater, K. F., and Hopwood, D. A.: Practical Streptomyces Genetics, The John Innes Foundation Norwich, England, 2000.

Kim, D., Ryu, H. D., Kim, M. S., Kim, J., and Lee, S. I.: Enhancing struvite precipitation potential for ammonia nitrogen removal in municipal landfill leachate, J. Hazard. Mater., 146, 81-85, 2007.

Kofina, A. N. and Koutsoukos, P. G.: Spontaneous Precipitation of Struvite from Synthetic Wastewater Solutions, Crystal Growth Des., 5, 489-496, 2005.

Konhauser, K. and Riding, R.: Bacterial Biomineralization, in: Fundamentals of Geobiology, edited by: Knoll, A. H., Canfield, D. E., and Konhauser, K. O., John Wiley \& Sons, Ltd, 105-130, 2012.

Le Corre, K. S., Valsami-Jones, E., Hobbs, P., and Parsons, S. A.: Impact of calcium on struvite crystal size, shape and purity, J. Cryst. Growth, 283, 514-522, 2005. 
Le Corre, K. S., Valsami-Jones, E., Hobbs, P., and Parsons, S. A.: Impact of reactor operation on success of struvite precipitation from synthetic liquors., Environ. Technol., 28, 1245-1256, 2007a.

Le Corre, K. S., Valsami-Jones, E., Hobbs, P., and Parsons, S. A.: Kinetics of Struvite Precipitation: Effect of the Magnesium Dose on Induction Times and Precipitation Rates, Environ. Technol., 28, 1317-1324, 2007b.

Lee, S. I., Weon, S. Y., Lee, C. W., and Koopman, B.: Removal of nitrogen and phosphate from wastewater by addition of bittern, Chemosphere, 51, 265-271, 2003.

Lowenstam, H. A.: Minerals formed by organisms, Science, 211, 1126-1131, 1981.

Lowenstam, H. A. and Weiner, S.: On biomineralization, Oxford University Press, Inc., New York, 1989.

Mann, S.: Mineralization in biological systems, Struct. Bonding, 54, 125-174, 1983.

McLean, R. J., Downey, J., Clapham, L., Wilson, J. W., and Nickel, J. C.: Pyrophosphate inhibition of Proteus mirabilis-induced struvite crystallization in vitro, Clin. Chim. Acta, 200, 107-117, 1991.

Ohlinger, K. N., Young, T. M., and Schroeder, E. D.: Predicting struvite formation in digestion, Water Res., 32, 3607-3614, 1998.

Párraga, J., Rivadeneyra, A. M., Martín-García, J. M., Delgado, R., and Delgado, G.: Precipitation of Carbonates by bacteria from a Saline Soil, in Matural and Artificial Soil Extracts, Geomicrobiol. J., 21, 55-66, 2004.

Pérez-García, I., Rivadeneyra, M. A., and Ramos, C.: The influence of $\mathrm{pH}$ on struvite formation by bacteria, Chemosphere, 18, 16331638, 1989.

Prywer, J. and Torzewska, A.: Bacterially Induced Struvite Growth from Synthetic Urine: Experimental and Theoretical Characterization of Crystal Morphology, Crystal Growth Des., 9, 35383543, 2009.

Prywer, J. and Torzewska, A.: Biomineralization of struvite crystals by Proteus mirabilis from artificial urine and their mesoscopic structure, Cryst. Res. Technol., 45, 1283-1289, 2010.

Reardon, C. L., Dohnalkova, A. C., Nachimuthu, P., Kennedy, D. W., Saffarini, D. A., Arey, B. W., Shi, L., Wang, Z., Moore, D., McLean, J. S., Moyles, D., Marshall, M. J., Zachara, J. M., Fredrickson, J. K., and Beliaev, A. S.: Role of outer-membrane cytochromes MtrC and OmcA in the biomineralization of ferrihydrite by Shewanella oneidensis MR-1, Geobiology, 8, 56-68, 2010.

Rivadeneyra, M. A., Calvo, C., González-Torres, M. C., PérezGarcía, I., and Ramos-Cormenzana, A.: Precipitation of struvite in urine medium by urease-positive and urease-negative Yersinia strains, Urol. Int., 45, 298-301, 1990.

Rivadeneyra, M. A., Pérez-García, I., and Ramos-Cormenzana, A.: Struvite precipitation by soil and fresh water bacteria, Curr. Microbiol., 24, 343-347, 1992.

Rivadeneyra, M. A., Gutierrez-Calderón, A., Rivadeneyra, A. M., and Ramos-Cormenzana, A.: A study of struvite precipitation and urease activity in bacteria isolated from patients with urinary infections and their possible involvement in the formation of renal calculi, Urol. Int., 63, 188-192, 1999.
Roncal-Herrero, T. and Oelkers, E. H.: Experimental determination of struvite dissolution and precipitation rates as a function of $\mathrm{pH}$, Appl. Geochem., 26, 921-928, 2011.

Ronteltap, M., Maurer, M., and Gujer, W.: The behaviour of pharmaceuticals and heavy metals during struvite precipitation in urine, Water Res., 41, 1859-1868, 2007.

Saidou, H., Korchef, A., Ben Moussa, S., and Ben Amor, M.: Struvite precipitation by the dissolved $\mathrm{CO} 2$ degasification technique: Impact of the airflow rate and $\mathrm{pH}$, Chemosphere, 74, 338-343, 2009.

Schmidt, A., Haferburg, G., Sineriz, M., Merten, D., Büchel, G., and Kothe, E.: Heavy metal resistance mechanisms in actinobacteria for survival in AMD contaminated soils, Chemie der ErdeGeochem., 65, 131-144, 2005.

Schmidt, A., Haferburg, G., Schmidt, A., Lischke, U., Merten, D., Ghergel, F., Büchel, G., and Kothe, E.: Heavy metal resistance to the extreme: Streptomyces strains from a former uranium mining area, Chemie der Erde-Geochem., 69, 35-44, 2008.

Schütze, E. and Kothe, E.: Heavy Metal-Resistant Streptomycetes in Soil, in: Soil Biology, Springer-Verlag Berlin Heidelberg, 2012.

Skinner, H. C. W.: Biominerals, Mineral. Mag., 69, 621-641, 2005.

Stefov, V., Soptrajanov, B., Kuzmanovski, I., Lutz, H. D., and Engelen, B.: Infrared and Raman spectra of magnesium ammonium phosphate hexahydrate (struvite) and its isomorphous analogues. III. Spectra of protiated and partially deuterated magnesium ammonium phosphate hexahydrate, J. Mol. Struct., 752, 60-67, 2005.

Veis, A.: Mineralization in an organic matrix framework, in: Biomineralization, edited by: Dove, P. M., Yoreo, J. J. D., and Weiner, S., Biogeochemistry of Earth Processes - Reviews in Mineralogy and Geochemistry, 2003.

Wang, X.-W., WangII, P., and Zheng, Y.-Q.: Crystal structure of hexaaquanickel(II) hydrogenphosphate monohydrate, $\left[\mathrm{Ni}\left(\mathrm{H}_{2} \mathrm{O}\right)_{6}\right]\left[\mathrm{HPO}_{4}\right] \times \mathrm{H}_{2} \mathrm{O}, \mathrm{Z}$. Kristallogr.-New Cryst. St., 220, 321-322, 2005.

Weiner, S. and Dove, P.: An overview of biomineralization and the problem of the vital effect, in: Biomineralization, edited by: Dove, P. M., Yoreo, J. J. D., and Weiner, S., Biogeochemistry of Earth Processes - Reviews in Mineralogy and Geochemistry, 2003.

Yakubovich, O. V., Massa, W., Soboleva, A. A., Dimitrova, O. V., and Urusov, V. S.: Crystal structure of a new synthetic homologue of the switzerite series, Dokl. Chem., 393, 262-269, 2003.

Zantua, M. I., Dumenil, L. C., and Bremner, J. M.: Relationships Between Soil Urease Activity and Other Soil Properties, Soil Sci. Soc. Am. J., 41, 350-352, 1977.

Zeien, H. and Brümmer, G. W.: Chemische Extraktion zur Bestimmung der Schwermetallbindungsformen in Böden, Mitteilungen der Deutsche Bodenkundliche Gesellschaft, Sonderheft 59/I, 505-515, 1989. 